Provided for non-commercial research and education use. Not for reproduction, distribution or commercial use.

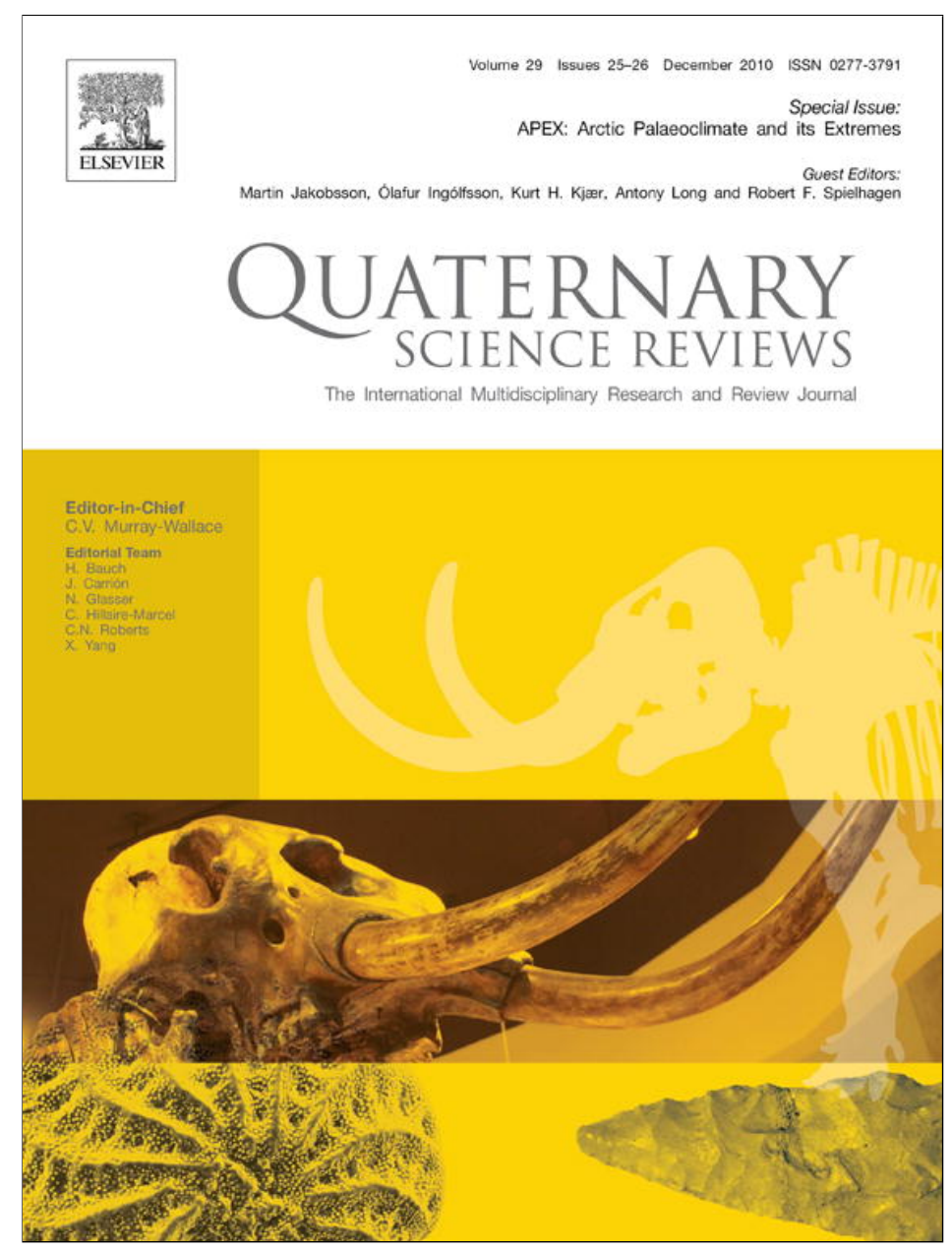

This article appeared in a journal published by Elsevier. The attached copy is furnished to the author for internal non-commercial research and education use, including for instruction at the authors institution and sharing with colleagues.

Other uses, including reproduction and distribution, or selling or licensing copies, or posting to personal, institutional or third party websites are prohibited.

In most cases authors are permitted to post their version of the article (e.g. in Word or Tex form) to their personal website or institutional repository. Authors requiring further information regarding Elsevier's archiving and manuscript policies are encouraged to visit:

http://www.elsevier.com/copyright 


\title{
New insights on Arctic Quaternary climate variability from palaeo-records and numerical modelling
}

\author{
Martin Jakobsson ${ }^{\mathrm{a}, *}$, Antony Long ${ }^{\mathrm{b}}$, Ólafur Ingólfsson ${ }^{\mathrm{c}}$, Kurt H. Kjær ${ }^{\mathrm{d}}$, Robert F. Spielhagen ${ }^{\mathrm{e}}$ \\ a Department of Geological Sciences, Stockholm University, 10691 Stockholm, Sweden \\ ${ }^{\mathrm{b}}$ Department of Geography, Durham University, Science Site, South Road, Durham DH1 3LE, UK \\ ${ }^{\mathrm{c}}$ Faculty of Earth Sciences, University of Iceland, Is-101 Reykjavik, Iceland \\ ${ }^{\mathrm{d}}$ Centre for GeoGenetics, Natural History Museum, University of Copenhagen, Øster Voldgade 5-7, DK-1350 Copenhagen, Denmark \\ ${ }^{\mathrm{e}}$ Academy of Sciences, Humanities and Literature, Mainz, and Leibniz Institute of Marine Sciences, IFM-GEOMAR, Wischhofstr. 1-3, D-24148 Kiel, Germany
}

\section{A R T I C L E I N F O}

Article history:

Accepted 26 August 2010

\begin{abstract}
A B S T R A C T
Terrestrial and marine geological archives in the Arctic contain information on environmental change through Quaternary interglacial-glacial cycles. The Arctic Palaeoclimate and its Extremes (APEX) scientific network aims to better understand the magnitude and frequency of past Arctic climate variability, with focus on the "extreme" versus the "normal" conditions of the climate system. One important motivation for studying the amplitude of past natural environmental changes in the Arctic is to better understand the role of this region in a global perspective and provide base-line conditions against which to explore potential future changes in Arctic climate under scenarios of global warming. In this review we identify several areas that are distinct to the present programme and highlight some recent advances presented in this special issue concerning Arctic palaeo-records and natural variability, including spatial and temporal variability of the Greenland Ice Sheet, Arctic Ocean sediment stratigraphy, past ice shelves and marginal marine ice sheets, and the Cenozoic history of Arctic Ocean sea ice in general and Holocene oscillations in sea ice concentrations in particular. The combined sea ice data suggest that the seasonal Arctic sea ice cover was strongly reduced during most of the early Holocene and there appear to have been periods of ice free summers in the central Arctic Ocean. This has important consequences for our understanding of the recent trend of declining sea ice, and calls for further research on causal links between Arctic climate and sea ice.
\end{abstract}

๑) 2010 Elsevier Ltd. All rights reserved.

\section{Introduction}

This special issue contains papers originating from the Second International Conference and Workshop on the Arctic Palaeoclimate and its Extremes (APEX) held in April 2008 at Durham University, UK (please see video file in Supplementary data). APEX is a scientific network program with a research focus that aims to better understand the magnitude and frequency of past Arctic climate variability and, in particular, the "extremes" versus the "normal" conditions of the climate system. During the closing of the Durham conference it was decided to develop a special issue focusing specifically on the palaeo-records (millennial, centennial, or decadal resolution) and natural variability of the Greenland Ice Sheet (GIS), Arctic Ocean sea ice, and Arctic ice shelves. These three topics also became the main themes for the Third APEX International Workshop and Conference held in April 2009 at the Natural History Museum, Denmark. Although the present issue mainly

\footnotetext{
* Corresponding author. Tel.: +46 81647 19; fax: +46 86747897.

E-mail address: martin.jakobsson@geo.su.se (M. Jakobsson).
}

contains contributions on these three topics, it is broadened by including the general Arctic Ocean history of marine ice sheets as well as several papers on other aspects of Arctic palaeoclimate change that are aligned with the APEX programme.

Supplementary video related to this article can be found at doi:10.1016/j.quascirev.2010.08.016.

In this introduction we first summarise the background and scientific focus of the APEX network program. This is followed by a brief description of the main findings of the papers included in this issue and an effort to bring these new results into a broad perspective considering both the historic and recent scientific literature. The papers cover both marine and terrestrial palaeorecords from a large geographical area of the Arctic region as well as studies involving numerical modelling (Fig. 1; Table 1).

\section{The Arctic Palaeoclimate and its Extremes (APEX)}

The APEX network idea was initiated October 2004 in Brorfelde, Denmark, with the aim to follow upon the two previously 


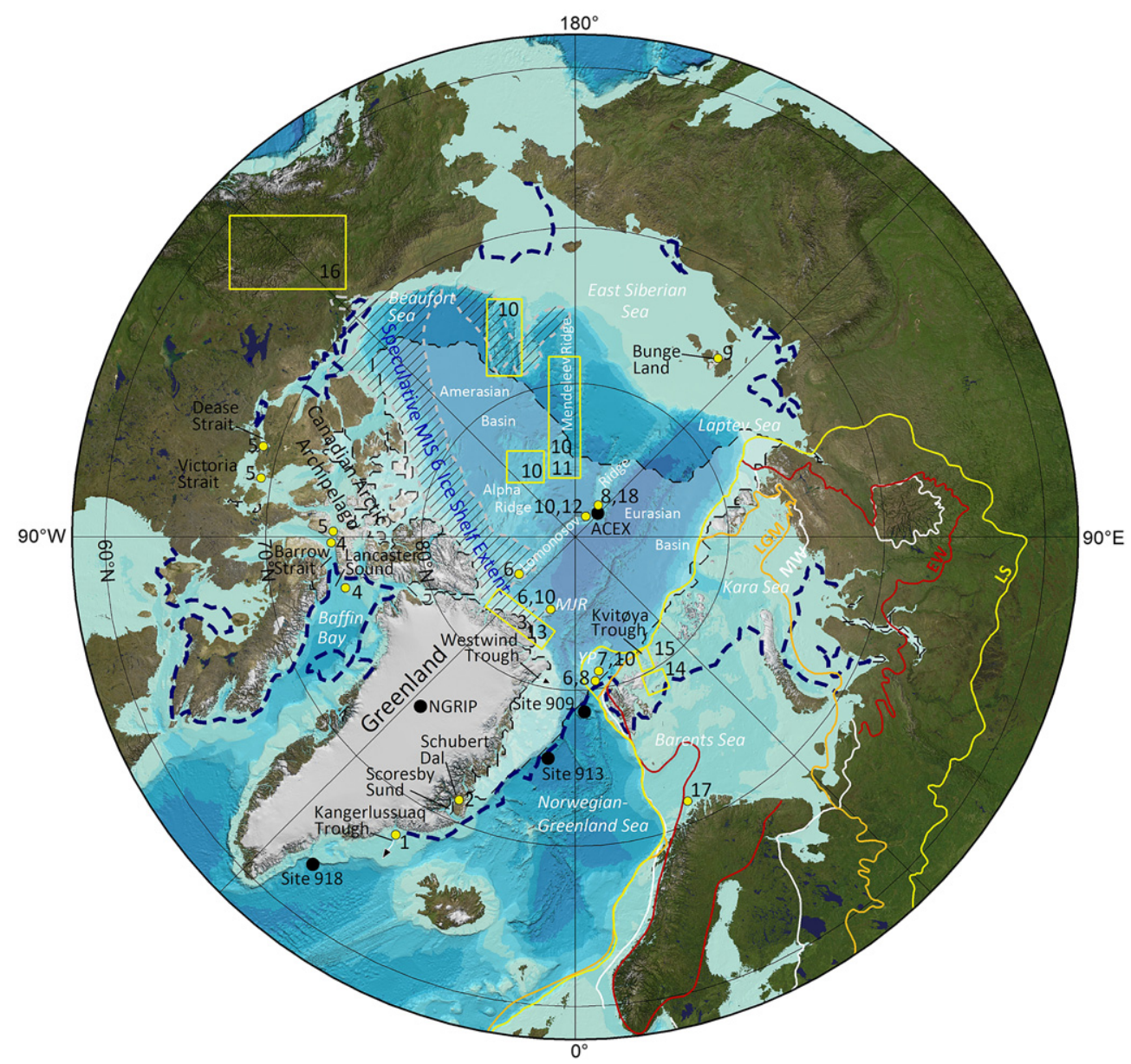

Fig. 1. Map showing the locations of some of the studies included in the papers presented in this special issue. Numbers refer to Table 1, which contains the references to the respective study. Some of the papers on the Arctic Ocean involve sediment cores from a large spatial area; these are only plotted with boxes enclosing the areas of the studied cores. Furthermore, Cronin et al. (2010) analyzed sediment cores from virtually the entire central Arctic Ocean and, therefore, there is no number representing that study on the map. The maximum extensions of the Eurasian Ice Sheet during the late Quaternary compiled by the QUEEN project (Svendsen et al., 2004) are shown. LS: Late Saalian (>140 ka), EW: Early Weichselian (100-80 ka), MW: Middle Weichselian (60-50 ka), LGM: Late Weichselian (25-15 ka). The speculative extent of an MIS 6 ice shelf inferred by Jakobsson et al. (2010) is shown by the hatched area enclosed by a gray stippled line. The approximate spatial minimum cover of sea ice during 2007 is shown with a white shaded area enclosed by a black stippled line as a comparison to the median extension for the period 1979-2005 shown by a blue stippled line (Data is from National Snow and Ice Data Center). MJR: Morris Jesup Rise; YP: Yermak Plateau.

successful research programs PONAM (Polar North Atlantic Margin: late Cenozoic Evolution) (Elverhøi et al., 1998) and QUEEN (Quaternary Environments of the Eurasian North) (Thiede et al., 2004). Both these programmes were focused on the palaeo-environment of the Arctic region with field work located mainly in Northern Eurasia, Svalbard and Greenland. APEX was developed as a contribution to the International Polar Year (IPY) 2007/2008 and was endorsed by the ICSU/WMO Joint Committee as one of the IPY "cluster" lead-coordinating program for palaeoclimate research. In order to continue after IPY, a proposal to the International Arctic Scientific Committee (IASC) for endorsement was developed. As a result, since 2008 APEX has operated as an endorsed IASC project organized by a Steering Committee (see www.apex.geo.su.se). Todate the network involves participating scientists from 15 European countries, Russia, Canada and USA. A special APEX issue of the journal Polar Research was published in 2008 (Jakobsson et al., 2008). The main scientific focus of this issue in Quaternary Science Reviews, and thus of APEX, is on Arctic extreme environments and centred around the following six research themes:

- Cold extremes: Arctic marine and terrestrial glacial maxima; sea level minima and sea ice maxima; Arctic Ocean palaeoceanography; ice shelf extent; past atmospheric circulation
- Warm extremes: interglacial and interstadial environments; sea level maxima; sea ice minima; Arctic Ocean palaeoceanography; ice shelf extent

- Hydrological extremes: fluvial-marine interaction; freshwater budget and ice-dammed lakes

- Permafrost extremes: maximum and minimum extent; rates of change; response to climate change

- Glacio-dynamical extremes: ice sheet configurations and instability; palaeo-ice stream dynamics and feedback mechanisms

- Biotic change: evolution of the Arctic marine and terrestrial biosphere and its response to extreme palaeoclimatic conditions; ice age development of human settlement

Our intention is that these themes provide the basis for a "bottom up" programme structure, within which individual research activities develop in a dynamic and mutually-supportive manner. A large set of field activities form the base for the APEX program of which several present results in this special issue.

By "Arctic Extremes" we mean conditions that occur at the end points of magnitude/frequency behaviour, such as maximum and minimum ice sheet extent, extreme ice flow, maximum and minimum air and water temperatures, or rapid changes in 
Table 1

Studies in this issue shown on the map in Fig. 1.

\begin{tabular}{lc}
\hline Reference & Number on map \\
\hline (Dowdeswell et al., 2010a) & 1 \\
(Hall et al., 2010) & 2 \\
(Möller et al., 2010) & 3 \\
(Ledu et al., 2010) & 4 \\
(Belt et al., 2010) & 5 \\
(Jakobsson et al., 2010) & 6 \\
(Dowdeswell et al., 2010b) & 7 \\
(O'Regan et al., 2010) & 8 \\
(Schirrmeister et al., 2010) & 9 \\
(Sellén et al., 2010) & 10 \\
(Not and Hillaire-Marcel, 2010) & 11 \\
(Hanslik et al., 2010) & 12 \\
(Larsen et al., 2010) & 13 \\
(Hogan et al., 2010a) & 14 \\
(Hogan et al., 2010b) & 15 \\
(Stroeven et al., 2010) & 16 \\
(Aagaard-Sørensen et al., 2010) & 17 \\
(Strand and Immonen, 2010) & 18 \\
\hline
\end{tabular}

palaeoceanography or vegetation. Their definitions are spatially and temporally specific, and may describe dimensions as well as causal processes. For example, the maximum past extent of Arctic Ocean ice shelves or the Eurasian Ice Sheet represents an extreme on the glacial-interglacial timescale, whereas the recent warming may be considered an extreme climatic event during the last thousand years. However, it is clear that to define an "extreme" we also need a robust understanding of the background, or "steady state" of a particular system. The six research themes listed above are designed with this definition of "Arctic Extremes" in mind, recognising that palaeo-studies are seldom restricted to one of these; instead most projects span over several of the themes. One other important reason for studying extremes is that they establish boundary conditions that constrain our understanding of the Arctic and the role of the Arctic in global climate change. These extremes are highly relevant to predictions of our future climate. From a modelling perspective, extremes also provide excellent targets that will help us achieve close cooperation between modellers and field scientists.

\section{Quaternary Arctic palaeo-records and natural variability}

\subsection{Greenland Ice Sheet}

In a recent review article, Alley et al. (2010) detail the broad spatial and temporal variability of the Greenland Ice Sheet (GIS) noting that, in general, periods of cooling caused ice sheet growth while periods of warming caused ice sheet shrinkage. However, this review also notes that there is considerable uncertainty regarding the patterns of ice sheet behaviour, both during previous warm periods such as the Eemian, i.e. Marine Isotope Stage (MIS) 5.5, and also during the Holocene. The challenge to the APEX community is therefore how to constrain periods of extreme ice sheet extent (maximum/minimum) and to understand the controls on these periods of change.

For a pre-Quaternary perspective on the GIS, including the first build-up of glaciers, one must look beyond the continent and into the adjacent deep sea sediment records. The onset of ice sheet build-up in the northern North Atlantic area was among the main scientific objectives for Ocean Drilling Program (ODP) Legs 151 and 162 , which both included sites in the Norwegian-Greenland Sea (Jansen and Raymo, 1996; Thiede and Myhre, 1996). Site 913 drilled during Leg 151 (Fig. 1) contains macroscopic drop-stones within a section of extensive ice-rafted debris (IRD) dated to the late
Eocene to early Oligocene (38-30 Ma) (Eldrett et al., 2007). The authors interpreted this increase in IRD and occurrence of dropstones to indicate the existence of, at the minimum, isolated glaciers on East Greenland that were calving icebergs into the North Atlantic. In fact, Leg 151 had close ties to PONAM and during this project analysis of Site 909, located in the Fram Strait (Fig. 1), showed the first IRD pulses in the middle Miocene at $14 \mathrm{Ma}$ (Thiede et al., 1998). However, since limited older sediments were recovered from Site 909, it is not possible to exclude that IRD events also occurred earlier here, as documented for Site 913 . Some $2200 \mathrm{~km}$ southwest of the Fram Strait, ODP Site 918 drilled during Leg 152 (Fig. 1), records an IRD increase in the late Miocene at about 7.3 Ma, suggesting that glaciers located on South East Greenland calved icebergs at this time (St. John and Krissek, 2002).

During the Late Quaternary, it is generally recognised that the GIS was significantly smaller than present during MIS 5.5, when air temperatures over Greenland may have been $5{ }^{\circ} \mathrm{C}$ warmer than today according to measured oxygen isotopes in the ice (North Greenland Ice Core Project members, 2004; see Fig. 1 for NGRIP site location). Recent modelling experiments suggest that this contracted ice sheet may have contributed up to $3 \mathrm{~m}$ to global sea level during this interval, although direct field evidence for the former ice sheet dimensions are very limited (Otto-Bliesner et al., 2006).

At the Last Glacial Maximum (LGM), there is growing evidence that the GIS extended a significant distance onto the continental shelf, a view supported by recent ice sheet modelling experiments (Simpson et al., 2009). During the early and mid part of the Holocene, rapid ice sheet retreat was associated with a removal of ice load and strong glacio-isostatic rebound and relative sea level fall (e.g. Funder and Hansen, 1996; Long et al., 2008). The ice sheet contracted to a smaller than present size in many areas by the end of the Holocene Thermal Maximum (HTM), but the exact dimensions of the ice sheet at this time remain speculative. Finally, during the late Holocene "Neoglacial", cooler conditions were associated with renewed ice sheet expansion of up to $60-80 \mathrm{~km}$ that culminated in the deposition of the Little Ice Age moraines, within a few kilometres of the present margin (Kelly, 1980; Hall et al., 2008; Simpson et al., 2009). This most recent phase of ice sheet history provides an important context against which to assess recent mass loss and ice margin retreat.

The Greenland papers in this special issue focus on the behaviour of the GIS since the LGM and provide new constraints on several of the issues outlined above. One of the general conclusions from the PONAM program is that there was a striking difference in the dynamics of the East GIS and the Svalbard-Barents Sea Ice Sheet over the last glacial cycle (Elverhøi et al., 1998). While the East GIS changed its outer bounds and, to some extent, thickness between stadials and interstadials, the neighbouring ice sheet across the Fram Strait nearly completely disintegrated during interstadials, growing again to reach the shelf edge during stadials. PONAM compiled a conceptual model illustrating these different behaviours and attributed them to varying paleoceanographic conditions in the North Atlantic (Elverhøi et al., 1998). After PONAM, further field work suggested the GIS expanded out onto the continental shelf during the LGM. In South East Greenland, for example, Jennings et al. (2006) placed the ice sheet margin in the Kangerdlussuaq Trough area at the shelf edge at $17 \mathrm{cal} \mathrm{ka} \mathrm{BP,} \mathrm{whilst} \mathrm{to} \mathrm{the}$ south of Ammassalik, Kuijpers et al. (2003) argue that the central shelf was ice free by $15 \mathrm{cal}$ ka BP. Further to the north, Ó Cofaig et al. (2004) present marine geophysical and sediment core evidence that provide strong support for ice sheet extent well onto the continental shelf, perhaps reaching as far as the shelf edge. This view has been supported more recently by the mapping of the Westwind ice stream across the continental shelf in Northeast 
Greenland (Evans et al., 2009) and by the identification of moraines associated with this ice stream that are attributed to a late glacial or early Holocene age (Winkelmann et al., 2010).

In this issue Dowdeswell et al. (2010a) present new swath bathymetric imagery that identify drumlins and glacial lineations produced by a former ice stream that occupied the Kangerlussuaq Trough (Fig. 1). They identify a convex debris fan at the trough mouth and suggest that the GIS probably expanded close to, if not all the way to, the shelf break outside of the Kangerlussuaq Trough during the LGM (Dowdeswell et al., 2010a). This is in agreement with recent ice sheet modelling in the area (Long et al., 2008; Simpson et al., 2009).

Most of the dating evidence from the ice free mainland of Greenland dates from the last 11-10 cal ka BP (Bennike and Björck, 2002) although there are a small number of regions where there is evidence for ice marginal formations during the Late Glacial and Younger Dryas. One such area is in Scoresby Sund, East Greenland (Fig. 1). In this issue, Hall et al. (2010) present a compilation of relative sea level data collected from raised marine deltas and other landforms in Schubert Dal that provide constraints on the timing of ice sheet recession during this interval. These data suggest a culmination of the Late glacial Milne Land Stade before 12.3-11.9 cal ka BP. Ice in Schubert Dal apparently retreated during the later part of the Younger Dryas, providing support for the hypothesis that this period was characterized by strong seasonality. The Hall et al. (2010) analysis also shows that the ice sheet had retreated close to or inland of its present position by the start of the Holocene, readvancing to its Holocene maximum during the Little Ice Age.

The third Greenland paper in this special issue also addresses the timing and nature of ice margin recession from the LGM into the Holocene, based on the study of the remote Constable Bugt region on the north coast of Greenland (Fig. 1). Here, Möller et al. (2010) identify evidence for a shelf-based glaciation during the LGM with ice flowing eastward along the coast, and also for two local valley glacier advances from the south that occurred during the Holocene. This study is important because it demonstrates the complex response of the ice sheet to periods of warmer and cooler than present conditions. During the warmth of the HTM, open sea ice conditions are indicated by the abundant deposition of open coast beach Ridges, which will be discussed further below in the context of the Arctic Ocean sea ice history.

Finally, Larsen et al. (2010) present regional mapping of glacial landforms and sediments from northernmost Greenland bordering $100 \mathrm{~km}$ of the Arctic Ocean coast (Fig. 1). One of the most important discoveries is that glacial landforms and sediments suggest eastward ice flow along the coastal plain. They argue that these findings are best explained by local outlet glaciers from the Greenland Ice Sheet and local ice caps that merged to form shelf-based ice in the Arctic Ocean and possibly confirming an extensive ice shelf in the Lincoln Sea between Greenland and Ellesmere Island. The existence of extensive shelf-based ice north of Greenland provides an important contribution to the understanding of the LGM glaciation history of the Arctic Ocean. Results show that the shelf-based ice started to build-up as early as 30 cal ka BP and reached a maximum during the Last Glacial Maximum (LGM). The shelf-based ice began to retreat ca. 16-10.3 cal ka BP before the final break up, which took place ca. 10.1 cal ka BP, probably as a combined result of increased inflow of warm Atlantic water through the Fram Strait, a shallower halocline and higher summer temperatures, corresponding to increased solar insolation at this time.

\subsection{Arctic Ocean sea ice}

The trend of declining Arctic Ocean sea ice extent and thickness observed over the last 30 years, with September 2007 so far holding the record low, has brought this particular polar issue into sharp focus (see review: Polyak et al., 2010) (Fig. 1). This declining trend was revealed from analysis of satellite imagery available since 1979 (e.g. Stroeve et al., 2007) and it has been suggested that it results from a combination of strong natural variability in the coupled iceocean-atmosphere system and an increased radiative effect from the rising level of atmospheric greenhouse gases due to human activities (Serreze et al., 2007). Neither PONAM nor QUEEN studied Arctic Ocean sea ice as one of their main research topics, although several of their studies addressed its Quaternary history indirectly from analysis of proxies such as IRD and micro-fossils in marine sediment cores (Jakobsson et al., 2001; Spielhagen et al., 2004). This has changed under APEX with past sea ice maxima/minima featuring as a key programme theme. This emphasis is reflected in the six papers included in this special issue that address the history of the Arctic Ocean sea ice from various perspectives. None of these studies extends further back in time than the Quaternary and it is therefore appropriate to view these new results in a Cenozoic perspective.

The Integrated Ocean Drilling Program (IODP) Arctic Coring Expedition (ACEX), drilled a $428 \mathrm{~m}$ long sediment record from the Lomonosov Ridge in the central Arctic Ocean (Backman and Moran, 2009) (Fig. 1). Studies of this sediment sequence provide the first glimpses of the long term Cenozoic history of Arctic Ocean sea ice. IRD first appears in the ACEX core at 46 Ma, in the middle Eocene, implying that ice, glacial or sea ice, rafted this material to the Ridge from this time onwards (St John, 2008). That sea ice appeared in the central Arctic in the early Eocene was subsequently supported by findings of sea ice-dependent fossil diatoms (Synedropsis spp.) and by analysis of the textural characteristics of the rafted quartz grains in the ACEX core (Stickley et al., 2009). A two-phase initiation of sea ice is suggested with formation of sea ice over the marginal shallow shelf areas by $\sim 47.5 \mathrm{Ma}$ followed by seasonal sea ice formation in the offshore Arctic Ocean by $\sim 47$ Ma (Stickley et al., 2009). Winter sea ice formation in marginal Arctic seas may have occurred as early as the middle Paleocene (Spielhagen and Tripati, 2009).

Icebergs or sea ice flows are the only possible agents that can transport sand sized particles to the central Arctic Ocean, but it is more difficult to determine when a perennial sea ice cover was first established in the Arctic Ocean from studies of sea bed sediments. Assuming that source areas for sediments analyzed in the ACEX record were geographically too far away to be rafted by seasonal sea ice, it is suggested that a perennial sea ice cover was established 14-13 Ma (Darby, 2008; Krylov et al., 2008). However, because of the relatively poor resolution of the ACEX core, no studies have yet resolved whether or not there have been periods when perennial sea ice cover disintegrated.

Like the sea ice-dependent diatoms of Synedropsis spp. mentioned above, the ostracode species Acetabulastoma arcticum is also dependent on sea ice as they live parasitically on pelagic amphipods that today exist only in perennially sea ice covered regions (Cronin et al., 2010). Therefore, the presence of this species is interpreted as evidence for the presence of perennial sea ice cover. In this issue, Cronin et al. (2010) use this assumption to calculate an $A$. arcticum sea ice index (AASII) to estimate the degree of perennial sea ice cover during the late Quaternary in the central Arctic Ocean as well as Iceland and Rockall Plateaus. The AASII suggests a high concentration of perennial ice in the central Arctic Ocean during MIS 3 (45-25 ka BP) with a minimum found between the last deglacial ( $16 \mathrm{ka}$ ) until the end of the Holocene Thermal Maximum (HTM), c 5 cal ka BP (Fig. 2). After the HTM, perennial sea ice cover increased again. The cores analysed from the Iceland and Rockall Plateaus suggest that a perennial sea ice cover existed here only during the peak of the glacial periods during MIS 6, 4 and 2. 


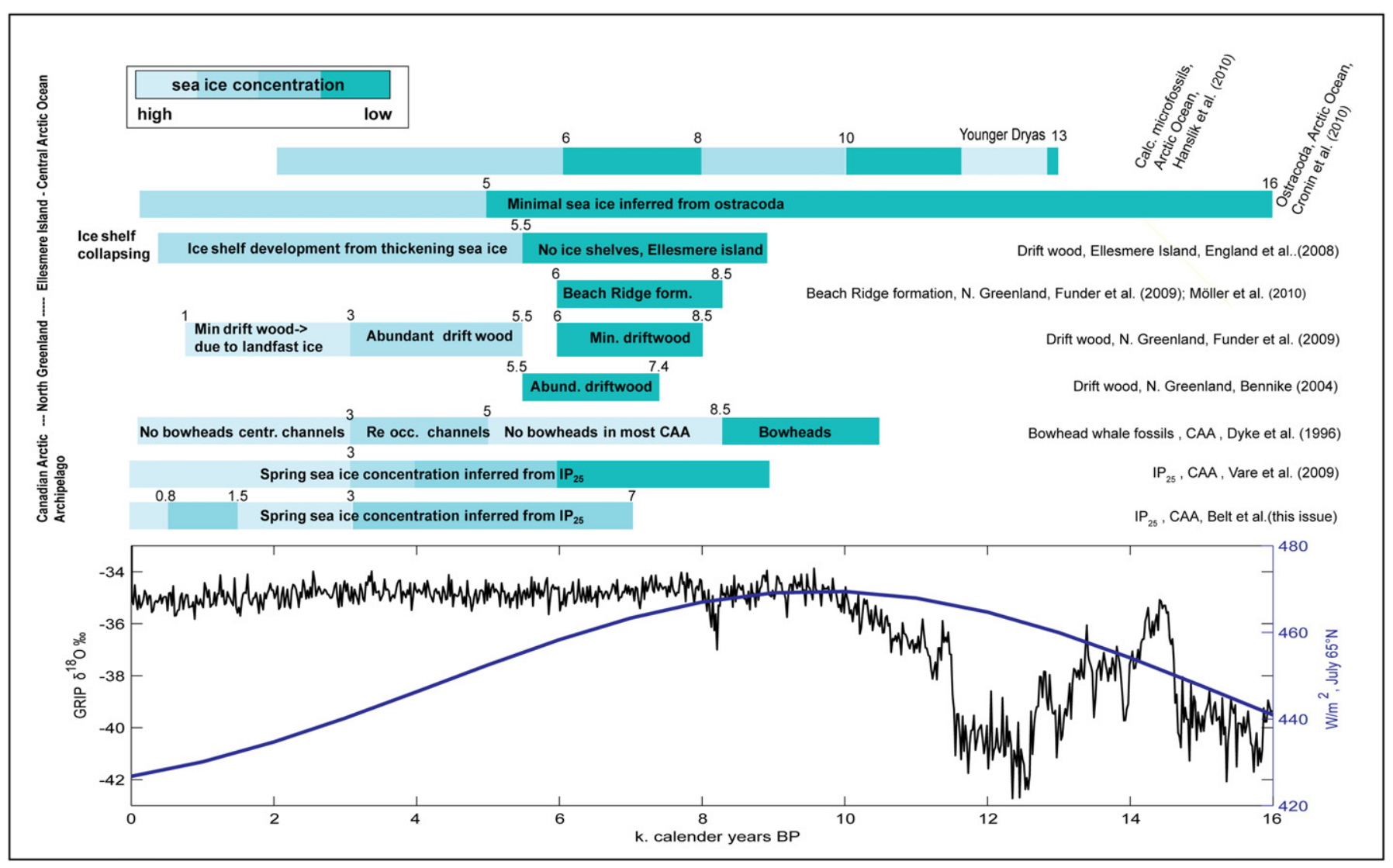

Fig. 2. Summary of results on the Arctic Ocean Sea ice variations over time presented in this issue as well as in previous studies. The inferred scale of sea ice concentration is an attempt to compare the results from the different studies, however, it must be regarded as a highly qualitative scale as none of the sea ice proxies provide and absolute measure of past sea ice concentrations. The GRIP $\delta^{18} \mathrm{O}$ record is from Johnsen et al. (2001) and the solar insolation from Berger and Loutre (1991).

Interestingly, a sediment core analyzed from the central Lomonosov Ridge reported in this issue by Hanslik et al. (2010) contains exceptionally high abundances of calcareous micro- and nannofossils during parts of MIS 3; as much as 30 times more nannofossils are counted per $\mathrm{mm}^{2}$ for MIS 3 peaks compared to that in MIS 1 deposits. The same abundance pattern is noted for both planktic and benthic foraminifera when comparing MIS 3 and 1. Hanslik et al. (2010) suggest that this signal may reflect different circulation regimes in the central Arctic Ocean with more inflow of Atlantic water during the MIS 3 interstadials, as well as less dense sea ice cover compared to the present interglacial, although they do not rule out that different sedimentation rates during the two periods may skew the results. Reduced sea ice during MIS 3 does not agree with the ostracode results of Cronin et al. (2010). On the other hand, there are similarities in the pattern of calcareous microfossil abundance variations during MIS 1 and the derived AASII; both indicate increasing sea ice cover from 6 to 5 cal ka BP (Fig. 2). The core from the Lomonosov Ridge studied by Hanslik et al. (2010) reveals prominent dips in abundance during the Younger Dryas cold period as well as $10-8 \mathrm{ka}$, suggesting that colder conditions and more severe sea ice cover existed at these times. This is not seen clearly in the AASII (Cronin et al., 2010).

The inflow of Atlantic Water is the major means of heat advection to the Arctic. Understanding of its modification by freshwater from river runoff, ice sheet meltwater, and sea ice melting is crucial for any prediction of future oceanic change in the Arctic. Similar interactions of Atlantic Water and freshwater occurred during the Last glacial-interglacial transition in the south western Barents Sea and are reported in this issue by AagaardSørensen et al. (2010). At decadal resolution the authors use a multiproxy approach to decipher the complex relationship of water masses, sea ice, and the decaying Scandinavian-Barents Sea ice sheet. They find that the transition from the last glacial maximum to the Holocene occurred in four major phases with highly variable oceanic conditions. Considering the recent reports on beginning interactions of warm ocean waters and the Greenland Ice Sheet (e.g. Straneo et al., 2010), high-resolution palaeo-studies of such developments are important contributions to our understanding of possible future Arctic changes.

As noted above, in this issue, Möller et al. (2010) suggest that the northernmost coast of Greenland experienced a period during the HTM when perennial sea ice, or the land-fast ice presently characterizing the region, was absent (Figs. 1 and 2). This suggestion is based on the existence of beach ridges that not could have been formed during conditions similar to those of today when both the land-fast ice and perennial sea ice prevented beach ridge formation by restricting wave height. The mapped ridges are dated to between about 8.5 and 6 cal ka BP (Möller et al., 2010) and it is interesting to compare these records with other geological records from Northern Greenland.

Driftwood stranded on Arctic beaches have been used previously as an indicator of past sea ice conditions (e.g. Häggblom, 1992). This is based on two main assumptions; 1 ) the near shore area must be ice free to allow the driftwood to strand, and 2) the driftwood floats for about 1-2 years, implying that longer time journeys over an open ocean require sea ice as the transport mechanism. The type of tree can be used to track the source region of the driftwood (Larix dominates in Siberia; Picea dominates in North America). Bennike (2004) found that driftwood older than 7.4 cal ka BP is rare on Northern Greenland beaches and suggests 
that this indicates more severe sea ice conditions than at present while between 6.8 and 5.5 cal ka BP the driftwood record from northeast Greenland suggests more open water conditions. However, at the APEX conference in Copenhagen 2009, Funder et al. (2009) proposed that the lack of driftwood findings in the area of Northern Greenland where beach ridges are mapped indicate summer sea ice free conditions in the central Arctic Ocean during the early Holocene (Fig. 2). Westward of northern Greenland driftwood has been found inside the multiyear land-fast sea ice that presently exists on the northern coast of Ellesmere Island. Dating of this driftwood indicates that there were no ice shelves in this region prior to 5.5 cal ka BP (England et al., 2008) (Fig. 2).

Considering these different lines of evidence, a picture begins to evolve suggesting that Arctic sea ice cover was strongly reduced during most of the early Holocene; there appears even to have been periods of ice free summers in large parts of the central Arctic Ocean (Fig. 2). The trend of declining sea ice, which clearly is seen since satellite images became available from 1979 (Stroeve et al., 2007), makes the early Holocene a particularly interesting period to study. Are we presently heading towards a time period with similarly low sea ice concentration as during the early Holocene? If so, what are the causes for this? Are there specific climatic analogies between the early Holocene and present conditions that are critical for Arctic Ocean perennial sea ice cover? One main difference is in the amount of solar radiation, which during the early Holocene peaked at 9 ka with about $8 \%$ more solar radiation to the Northern Hemisphere in summer (Fig. 2). The question of seasonal Arctic Ocean sea ice extent through the Holocene also has implications for marine mammals depending on sea ice for their survival. It has been suggested that if sea ice concentrations continue to decrease, it could seriously threaten the survival of the Polar Bear (Ursus maritimus) (Derocher et al., 2004). Recent studies by Ingólfsson and Wiig (2009) and Lindqvist et al. (2010) show that polar bears survived the Eemian interglacial and the early Holocene, suggesting they have under natural conditions the ability to survive periods of low sea ice concentrations.

In this issue, Dyck et al. (2010) use a coupled ice-ocean model to study the early Holocene at $8 \mathrm{ka}$ and the sensitivity of selected ocean and atmospheric forcing parameters on sea ice. In their simulations, forcing of winds, ocean currents and surface air temperatures are taken from conditions observed in recent years that are characterized by a positive North Atlantic Oscillation (NAO) phase. Solar radiation and surface air/ocean temperatures are modified since, as noted above, these are known to have been different during the early Holocene. Their simulations suggest that sea ice at $8 \mathrm{ka}$ was thinner than today in the East Siberian and Laptev seas while there was little change in the Beaufort Sea and Canadian Arctic Archipelago. The largest reduction in concentration is simulated in the Barents Sea where sea ice thickness is generally reduced at $8 \mathrm{ka}$ compared with today. The main forcing effect is found to be from the atmosphere, in particular warmer surface air temperatures that had a negative effect on sea ice. Local wind patterns are also shown to greatly impact the sea ice extent and thickness.

Several previous studies provide information on the sea ice conditions during the Holocene in the Canadian Arctic Archipelago. Some of these use the distribution of fossils of the bowhead whale (Balaena mysticetus), which lives in the loose pack ice edge and follows the ice edge's seasonal migration. Therefore, the distribution of their fossils in beach deposits can be used as an added proxy for summer sea ice minima (Dyke et al., 1996; Dyke and England, 2003). The whales migrate both from the Pacific and Atlantic sides, but populations rarely met due to the persistent sea ice cover with few open leads in the central Canadian Arctic Archipelago. However, between 10.5 and $8.5 \mathrm{cal} \mathrm{ka}$ BP, sea ice conditions were sufficiently benign in the central Canadian Arctic Archipelago for the bowhead whale to extend from the Baffin Bay on the Atlantic side to the Beaufort Sea (Fig. 2) (Dyke et al., 1996). Conditions then changed and during $8.5-5 \mathrm{cal}$ ka BP sea ice was more severe in the Canadian Arctic Archipelago than at present. A return to lighter sea ice conditions allowed the whales to reoccupy the inner channels of the archipelago at about $5 \mathrm{cal} \mathrm{ka} \mathrm{BP}$ and these conditions prevailed until 3 cal ka BP when again, summer sea ice prevented the whales from reaching the inner channels. The sea ice pattern of the Canadian Arctic Archipelago inferred from the bowhead whale record shows some striking differences compared to other Arctic Ocean records (Fig. 2).

Another proxy for sea ice concentration, as well as salinity and temperature, are dinoflagellate cyst assemblages (Vernal et al., 2008). This proxy is used by Ledu et al. (2010) in an analysis of sediment cores collected from Lancaster Sound and Barrow Strait (Fig. 1). Their results suggest summer sea surface temperatures $2^{\circ} \mathrm{C}$ cooler than present in the Lancaster Sound area between 10.8 and 9 cal ka BP while the period of the HTM was $3{ }^{\circ} \mathrm{C}$ warmer than present. Sea ice concentration increased after the HTM and remained harsh until present.

The final contribution on the history of the Arctic Ocean sea ice in this issue is based on the biomarker $\mathrm{IP}_{25}$, which derives from sea ice dependant diatoms (see Belt et al., 2007). Based on the $\mathrm{IP}_{25}$ variations in sediment cores from Barrow, Victoria and Dease Straits in Canadian Arctic Archipelago (see Fig. 1) Belt et al. (2010) infer low spring sea ice concentrations during 7-3 cal ka BP and 1.5-0.8 cal ka BP (Fig. 2) and higher concentrations between 3 and $1.5 \mathrm{cal}$ ka BP and after 0.8 cal ka BP (Fig. 2). The previous study by Vare et al. (2009) from this region using $\mathrm{IP}_{25}$ extend further back in time and suggests that the early Holocene between 10 and 6 cal ka BP was characterized by low spring sea ice concentrations.

\subsection{Central Arctic Ocean ice shelves and marginal marine ice sheets}

The focus of QUEEN was on the Arctic sector of Eurasia and the project included an effort to use new field work observations with aerial photographs and satellite images to construct maps of maximum ice sheet extents for the Late Saalian ( $>140 \mathrm{ka}$ ), the Early Weichselian (100-80 ka), the Middle Weichselian (60-50 ka) and the Late Weichselian (25-15 ka) (Svendsen et al., 2004) (Fig. 1). A comparable effort of synthesizing all field work into maps of past ice sheet extents was not carried out during PONAM. However, as mentioned above a conceptual model was developed that schematically illustrated the extents of the East GIS and the SvalbardBarents Sea Ice Sheet during the late Quaternary glaciations. The central Arctic Ocean glacial history was not part of any of these synthesising efforts, although, during the time of QUEEN glacial erosion was mapped for the first time at $1000 \mathrm{~m}$ water depth on the Lomonosov Ridge close to the North Pole (Jakobsson, 1999; Polyak et al., 2001) (Fig. 1). These results brought new life into the debate on the existence of a continuous $1000 \mathrm{~m}$ thick ice shelf occupying the Arctic Ocean during the LGM (e.g. Hughes et al., 1977; Grosswald and Hughes, 2008). However, QUEEN showed that the LGM ice sheet had limited extension eastward of the Kara Sea (Svendsen et al., 2004) and the ice grounding on the Lomonosov Ridge is dated to have occurred during MIS 6, i.e. the Late Saalian (Jakobsson et al., 2001).

In this issue Jakobsson et al. (2010) show new multibeam swath bathymetry and subbottom profiling data from the southern Lomonosov Ridge north of Greenland, Morris Jesup Rise, and Yermak Plateau revealing glaciogenic features that provide new insights into the Arctic Ocean glacial history. Their geophysical mapping data, in combination with sediment cores constraining the age of the glaciogenic features, suggest that an extensive 
marine ice sheet complex including a floating ice shelf existed in the Amerasian Arctic Ocean during MIS 6 (Fig. 1). The extent of this ice shelf is speculatively outlined and from a conceptual oceanographic model it is suggested that favourable conditions for ice shelf development may have been caused during MIS 6 by a deepening of the cold halocline of the Polar Surface Water that inhibited warm Atlantic water from reaching the Amerasian Arctic Ocean and prevented ice shelf development. The importance of the oceanic conditions was previously discussed by Mercer (1970) who was the first to develop the hypothesis of an Arctic Ocean ice shelf from physiographic similarities between the Arctic Ocean and the former sea now occupied by the West Antarctic Ice Sheet.

Iceberg ploughmarks at present water depths down to $850 \mathrm{~m}$ on the southern Yermak Plateau were first mapped by Vogt et al. (1994) who also discovered that the 510-530 m flattened southern plateau crest had been subjected to extensive ice grounding. This area of the plateau has been revisited by Dowdeswell et al. (2010b). Their multibeam swath bathymetric imagery show glacial lineations on the flattened crest that are similar to mega-scale glacial lineations that are common where ice sheets have deformed the sediments at the base (e.g. Clark, 1993; King et al., 2009). Interestingly, the orientation and nature of the lineations are such that Dowdeswell et al. (2010b) suggest that the most likely explanation for their formation is by the drift across the plateau of an ice shelf remnant or megaberg from the central Arctic Ocean. Sediment cores constrain the age of the glacial lineations to MIS 6 and, as suggested by Jakobsson et al. (2010), the proposed marine ice sheet complex including a floating ice shelf in the Amerasian Basin seems a likely source for the ice shelf remnant or megaberg.

Geotechnical properties of sediment cores retrieved from the ice grounded areas of southern Yermak Plateau and central Lomonosov Ridge are investigated in this issue by O'Regan et al. (2010) (Fig. 1). The geotechnical analyses show sediment consolidation and/or deformation that most likely is caused from loading of grounded ice and not from removal of sediments through erosion, except for in one area on the Lomonosov Ridge. The analysis of cores from the southern Yermak Plateau suggest a more transient, short duration, ice grounding compatible with the grounding of a drifting ice shelf remnant or megaberg rather than longer time duration loading of an ice sheet extending from northern Svalbard. This result implies that the Late Saalian ice sheet extension compiled by QUEEN (Svendsen et al., 2004) should be slightly modified for the southern Yermak Plateau (Fig. 1). While several new results indicate that MIS 6 comprised the most extensive Arctic Ocean Quaternary marine ice complex, Strand and Immonen (2010) suggests from studies of quartz sand grain microtextures, in a core from the central Lomonosov, that the Barents-Kara Ice Sheet was thicker and likely more extensive during MIS 4 than during LGM (Fig. 1).

Colleoni et al. (2010) use Atmospheric General Circulation Modelling (AGCM) to explore how extensive MIS 6 ice shelves in the Arctic Ocean could have influenced climate and the mass balance of the large contemporary continental ice sheets, in particular the huge Late Saalian Eurasian Ice Sheet. Both the impact from a limited ice shelf in the Amerasian Basin (Jakobsson et al., 2010) and a continuous $1000 \mathrm{~m}$ thick ice shelf covering the entire Arctic Ocean (e.g. Hughes et al., 1977) is investigated. The inferred ice shelves clearly have regional cooling effects since they insolate heat flux from the underlying ocean and combined with the, albeit relatively low, surface elevation prevent the snow cover from melting during summer. But this cooling effect does not spread far and only affects the outer margins of the circum Arctic continental ice sheets. Therefore, Colleoni et al. (2010) does not find that the existence of a MIS 6 Arctic Ocean ice shelf, restricted or covering the entire Arctic Ocean, could be the main explanation for why the
Eurasian Late Saalian Ice Sheet grew so large as proposed by QUEEN (Svendsen et al., 2004) (Fig. 1).

\subsection{The Siberian and Canadian Arctic}

Considerable progress in our understanding of Quaternary palaeoclimate was achieved by the QUEEN project as a result of research undertaken in Russia. This issue contains two papers that add to this body of knowledge, both of which confirm the huge potential of the Russian Arctic for palaeoclimate research.

The first paper, by Schirrmeister et al. (2010), describes preliminary results arising from an investigation of the Late Glacial to Holocene landscape and environmental history of Bunge Land (Zemelya Bunge) in the New Siberian Archipelago (Fig. 1). Using a combination of datasets, Schirrmeister et al. (2010) reconstruct one of the northernmost environmental records from this time in the Eurasian Arctic. They identify a buried thermokarst landscape in the northwest region of the Bunge Land that experienced seismotectonical block movements following deposition. The terrace area subsided and the original landscape was flooded and buried by extensive marine sediments. Subsequent block heave exposed a vast sheet of then marine sands, which have since been reworked by eolian processes.

In the second paper, Astakhov and Nazarov (2010) develops a new geochronological correlation scheme that, for the first time, reconciles records of palaeoclimate change in West Siberia with that in Northwest Europe. The scheme is based on a large database of Optically Stimulated Luminescence (OSL), radiocarbon and U/Th dates from 24 sections in West Siberia, many of which are from previously undated (or poorly dated) sections. The work shows that elements of the traditional West Siberian stratigraphic scheme, notably assumed sequences of Eemian and Middle Pleniglacial age, are no longer valid. The revised scheme enables, for the first time, agreement between the European and Siberian chronostratigraphic models.

In contrast to the Russian Arctic, QUEEN and PONAM paid limited attention to developments in the Canadian Arctic. A welcome feature of APEX is the inclusion of workers from the latter region into the current project and one paper in this issue addresses ice sheet reconstructions in this region. Stroeven et al. (2010) use cosmogenic radionuclide dating of quartz to develop a chronology for the glacial history of the northern sector of the Cordilleran Ice Sheet in central Yukon (Fig. 1). Forty-three samples of bedrock, erratics, and moraine boulders from eight areas demonstrate considerable age spread. However, bedrock surface exposure ages provide evidence for a possible MIS 6 age for the Reid glaciation. An alpine glacier advance in the Glenlyon Range is cautiously ascribed $a>40 \mathrm{ka}$ age. Results from other sites provide complementary dating control on successive glacial phases culminating in the LGM and the Late Glacial, and demonstrate the potential of the method to provide lateral and vertical constraints on ice sheet extent.

\subsection{Arctic Ocean sediment stratigraphy}

During QUEEN an intensive discussion existed within the marine geological group about the age models established in sediment cores from the central Arctic Ocean. At the time, it was generally accepted that the Plio-Pleistocene Arctic Ocean is characterized by extremely low sedimentation rates on the order of $\mathrm{mm} / \mathrm{ka}$. This view was primarily based on cores retrieved from ice island T-3, drifting over the Amerasian Basin, and the assumption that the first magnetic reversal recorded in these cores represents the Brunhes/Matuyama paleomagnetic reversal (Clark, 1970). Central to the low sedimentation rate hypothesis is the thought that sediment deposition diminished dramatically when the first 
perennial sea ice formed over the Arctic Ocean (Clark, 1971). Several studies prior to the time of QUEEN had proposed higher PlioPleistocene sedimentation rates in the central Arctic Ocean (e.g. van Donk and Mathieu, 1969; Sejrup et al., 1984), but it was during QUEEN that new dating results of sediment cores began changing the common view (Jakobsson et al., 2000; Backman et al., 2004; Spielhagen et al., 2004). Finally, the Neogene age model of the ACEX drill core from the Lomonosov Ridge, derived using dinoflagellate and foraminifera markers, and the down-core decrease of ${ }^{10} \mathrm{Be} /{ }^{9} \mathrm{Be}$, and cyclostratigraphy, suggest that $\mathrm{cm} / \mathrm{ka}$ sedimentation rates prevailed during the Plio-Pleistocene in this part of the Arctic Ocean (Backman et al., 2008; Frank et al., 2008; O'Regan et al., 2008).

Two studies in this issue suggest that the northern Mendeleev and Alpha Ridge area of the Amerasian Basin is characterized by lower sedimentation rates than the rest of the Arctic Ocean, likely due to the sluggish Beaufort Gyre that dominates the surface circulation in this area during present oceanographic conditions (Fig. 1). The first by Sellén et al. (2010) is based on cores retrieved during the Healy-Oden Trans-Arctic Expedition (HOTRAX) 2005 and the Lomonosov Ridge off Greenland Expedition (LOMROG) 2007 (Fig. 1). They suggest that there are at least three prominent stratigraphic markers that can be used on a basin-wide scale to allow a comparison between the sedimentary environment in the Eurasian Basin and Amerasian Basin. Perhaps the most conspicuous of these markers is the first encountered prominent paleomagnetic inclination change, which occurs in the stratigraphy in all cores, from the southern part of the Mendeleev Ridge, across the Arctic Ocean and the Lomonosov Ridge to the Morris Jesup Rise. This inclination change occurs towards the end of MIS 7 according to the established chronostratigraphy by Sellén et al. (2010), but was ascribed earlier (e.g. Clark, 1970) to the Brunhes/Matuyama boundary, which has a present inferred age of $780 \mathrm{ka}$ (Lourens et al., 2004).

Sellén et al. (2010) point to the recent study of Channell and Xuan (2009), which shows that inclinations in Arctic Ocean cores may, in fact, not at all be related to the "real" established and dated paleomagnetic reversals and/or shorter duration magnetic excursions. Instead paleoceanographic conditions on a basin-wide scale in combination with relatively low sedimentation rates may have generated near bottom environments where oxidation processes caused titano-magnetities to transform into titano-maghematites and, during this diagenetic change, acquire a chemical remnant magnetization that is partially self reversed (Channell and Xuan, 2009). This implies that even if the first prominent down-core inclination change does not represent one of the proper excursions, it may be a useful paleoceanographic marker, which according Sellén et al. (2010) occurs in MIS 7.

The second study in this special issue addressing Plio-Pleistocene sedimentation rates in the Amerasian Basin is by Not and Hillaire-Marcel (2010). They use decay of the radionuclides ${ }^{230} \mathrm{Th}$ and ${ }^{231} \mathrm{~Pa}$ to estimate sedimentation rates in cores retrieved during HOTRAX 2005 from the Mendeleev Ridge (Fig. 1). Their results suggest extremely low deposition with a mean rate of about $1.5 \mathrm{~mm} / \mathrm{ka}$, in line with the earlier studies by e.g. Clark (1970). However, average sedimentation rates in the central Arctic Ocean over longer time periods must be compared with great caution since there are indications of large fluctuations over time. For example, Hanslik et al. (2010) note that MIS 2 appears to be absent in the studied core from the Lomonosov Ridge, and this is also found in cores from the Amerasian Basin (Adler et al., 2009). This may be linked to the presence of extensive ice shelves (Dowdeswell et al., 2010b; Jakobsson et al., 2010) and overall cold oceanographic conditions during glacial periods preventing melt out and delivery of sediments. However, Sellén et al. (2010) show in their study on spatial and temporal sediment depositional regimes in the Arctic Ocean that the MIS 6 glacial period, the period when the most extensive ice shelf is proposed to have existed (Jakobsson et al., 2010), is particularly characterized by a prominent increase in coarse grain $(>63 \mu \mathrm{m})$ material. Such an increase in coarse grains is also found in some regions for the subsequent glaciations. These coarse grain peaks may be related to the ice sheet break up and not necessarily to the peak of the glaciation with maximum ice sheet extents.

\section{Concluding remarks}

APEX is now up and running - we have now established a growing community of scholars from Europe, Russia and America who are working to address critical questions regarding Arctic palaeoclimate and its extremes. The papers in this issue demonstrate the breadth of topics being considered that span the full range of terrestrial to marine records and which are closely integrated with modelling.

This review of APEX research identifies several areas that are distinct to the present programme and that represent significant advances on previous work in QUEEN and PONAM. The Arctic Ocean was essentially terra incognita in these earlier programmes, playing second fiddle to the terrestrial records of Arctic palaeoclimate, but in APEX it now occupies a central part of the Arctic palaeoclimate system and the current research programme. Understanding the links between climate change, palaeoceanography, sea ice extent and land-based ice is a challenge that APEX is now well-positioned to address. Future work should look to develop an integrated reconstruction of terrestrial and marine based evidence for ice sheet and ice shelf history in the Arctic Ocean and surrounding land masses. This is beginning to happen in the papers within this issue - the terrestrial history of the Greenland Ice Sheet is being integrated into the continental and deep ocean records, as are the ice sheets of Eurasia. Further advances are expected in the Canadian and Siberian arctic in coming years. A second area of future focus will be to improve our understanding of conditions during the periods of significantly greater than present ice extent (MIS6) and periods of much reduced ice cover (MIS 5e and the Holocene thermal optimum). The latter provides important base-line conditions against which to explore potential future changes in Arctic climate under scenarios of global warming.

\section{Acknowledgement}

IASC endorsed APEX in 2008 and has since then provided support for the international conferences and workshops. In addition, support has been provided by the ESF European Polar Board and the Bert Bolin Centre for Climate Research at Stockholm University as well as the universities and organizations hosting the APEX venues including Durham University, Geological Museum of University of Copenhagen, Stockholm University, the Royal Swedish Academy of Sciences, and University of Iceland. Matthew O'Regan and QSR Editor Colin Murray-Wallace provided comments that greatly improved the manuscript.

\section{References}

Aagaard-Sørensen, S., Husum, K., Hald, M., Knies, J. Paleoceanographic development in the SW Barents Sea during the late Weichselian - early Holocene transition. Quaternary Science Reviews 2010, doi:10.1016/j.quascirev.2010.08.014.

Adler, R.E., Polyak, L., Ortiz, J.D., Kaufman, D.S., Channell, J.E.T., Xuan, C., Grottoli, A.G., Sellén, E., Crawford, K.A., 2009. Sediment record from the western Arctic Ocean with an improved late Quaternary age resolution: HOTRAX core HLY0503-8JPC, Mendeleev Ridge. Global and Planetary Change 68, 18-29.

Alley, R.B., Andrews, J.T., Brigham-Grette, J., Clarke, G.K.C., Cuffey, K.M., Fitzpatrick, J.J., Funder, S., Marshall, S.J., Miller, G.H., Mitrovica, J.X., Muhs, D.R. 
Otto-Bliesner, B.L., Polyak, L., White, J.W.C., 2010. History of the Greenland Ice Sheet: paleoclimatic insights. Quaternary Science Reviews 29, 1728-1756.

Astakhov, V., Nazarov, D., 2010. Correlation of Upper Pleistocene sediments in northern West Siberia. Quaternary Science Reviews, doi:10.1016/j.quascirev. 2010.09.001.

Backman, J., Moran, K., 2009. Expanding the Cenozoic paleoceanographic record in the central Arctic Ocean: IODP Expedition 302 synthesis. Central European Journal of Geosciences 1, 157-175.

Backman, J., Jakobsson, M., Løvlie, R., Polyak, L., Febo, L.A., 2004. Is the central Arctic Ocean a sediment starved basin? Quaternary Science Reviews 23, 1435-1454.

Backman, J., Jakobsson, M., Frank, M., Sangiorgi, F., Brinkhuis, H., Stickley, C., O’Regan, M., Løvlie, R., Pälike, H., Spofforth, D., Gattacecca, J., Moran, K., King, J., Heil, C., 2008. Age model and core-seismic integration for the Cenozoic Arctic Coring expedition sediments from the Lomonosov Ridge. Paleoceanography 23, PA1S03.

Belt, S.T., Massé, G., Rowland, S.J., Poulin, M., Michel, C., LeBlanc, B., 2007. A novel chemical fossil of palaeo sea ice: IP25. Organic Geochemistry 38, 16-27.

Belt, S.T., Vare, L.L., Masse, G., Manners, H.R., Price, J.C., MacLachlan, S.E., Andrews, J.T., Schmidt, S., 2010. Striking similarities in temporal changes to spring sea ice occurrence across the central Canadian Arctic Archipelago over the last 7000 years, Quaternary Science Reviews. doi:10.1016/j.quascirev.2010.06.041.

Bennike, O., 2004. Holocene sea-ice variations in Greenland: onshore evidence. The Holocene 14, 607-613.

Bennike, O., Björck, S., 2002. Chronology of the last recession of the Greenland Ice Sheet. Journal of Quaternary Science 17, 211-219.

Berger, A., Loutre, M.F., 1991. Insolation values for the climate of the last 10 million years. Quaternary Science Reviews 10, 297-317.

Channell, J.E.T., Xuan, C., 2009. Self-reversal and apparent magnetic excursions in Arctic sediments. Earth and Planetary Science Letters 284, 124-131.

Clark, D.L., 1970. Magnetic reversals and sedimentation rates in the Arctic Ocean. Geological Society of America Bulletin 81, 3129-3134.

Clark, D.L., 1971. Arctic Ocean ice cover and its late Cenozoic history. Geological Society of America Bulletin 82, 3313-3324.

Clark, C.D., 1993. Mega-scale glacial lineations and cross-cutting ice-flow landforms. Earth Surface Processes and Landforms 18, 1-29.

Colleoni, F., Krinner, G., Jakobsson, M., 2010. The role of an Arctic ice shelf in the climate of the last glacial maximum of MIS 6 (140 ka). Quaternary Science Reviews, doi:10. 1016/j.quascirev.2010.06.023.

Cronin, T.M., Gemery, L., Briggs Jr., W.M., Jakobsson, M., Polyak, L., Brouwers, E.M., 2010. Quaternary Sea-ice history in the Arctic Ocean based on a new Ostracode sea-ice proxy. Quaternary Science Reviews, doi:10.1016/j.quascirev.2010.05.024.

Darby, D.A., 2008. Arctic perennial ice cover over the last 14 million years. Paleoceanography 23, PA1S07.

Derocher, A.E., Lunn, N.J., Stirling, I., 2004. Polar bears in a warming climate. Integrative and Comparative Biology 44

Dowdeswell, J.A., Evans, J., Cofaigh, C.Ó., 2010a. Submarine landforms and shallow acoustic stratigraphy of a $400 \mathrm{~km}$-long fjord-shelf-slope transect, Kangerlussuaq margin, East Greenland. Quaternary Science Reviews, doi:10.1016/j. quascirev.2010.06.006.

Dowdeswell, J.A., Jakobsson, M., Hogan, K.A., O’Regan, M., Antony, D., Backman, J., Darby, D., Eriksson, B., Evans, D.J.A., Hell, B., Janzen, T., Löwemark, L., Marcussen, C., Noormets, R., Ó Cofaig, C., Polyak, L., Sellén, E., Sölvsten, M., 2010b. Highresolution geophysical observations from the Yermak Plateau and northern Svalbard margin: implications for ice-sheet grounding and deep-keeled icebergs. Quaternary Science Reviews, doi:10.1016/j.quascirev.2010.06.002.

Dyck, S., Tremblay, L.B., de Vernal, A.,2010. Arctic sea-ice cover from the early Holocene: the role of atmospheric circulation patterns. Quaternary Science Reviews, doi:10.1016/j.quascirev.2010.05.008.

Dyke, A.S., England, J.H., 2003. Canada's most northerly Postglacial bowhead whales (Balaena mysticetus): Holocene sea-ice conditions and Polynya development. Arctic 56, 14-20.

Dyke, A.S., Hooper, J., Savelle, J.M., 1996. A history of sea ice in the Canadian Arctic Archipelago based on Postglacial remains of the bowhead whale (Balaena mysticetus). Arctic 49, 235-255.

Eldrett, J.S., Harding, I.C., Wilson, P.A., Butler, E., Roberts, A.P., 2007. Continental ice in Greenland during the Eocene and Oligocene. Nature 446, 176-179.

Elverhøi, A., Dowdeswell, J.A., Funder, S., Mangerud, J., Stein, R., 1998. Glacial and oceanic history of the Polar North Atlantic margins: an overview. Quaternary Science Reviews 17, 1-10.

England, J.H., Lakeman, T.R., Lemmen, D.S., Bednarski, J.M., Stewart, T.G., Evans, D.J.A., 2008. A millennial-scale record of Arctic Ocean sea ice variability and the demise of the Ellesmere Island ice shelves. Geophysical Research Letters 35.

Evans, J., Ó Cofaig, C., Dowdeswell, J.A., Wadhams, P., 2009. Marine geophysical evidence for former expansion and flow of the Greenland Ice Sheet across the north-east Greenland continental shelf. Journal of Quaternary Science.

Frank, M., Backman, J., Jakobsson, M., Moran, K., O’Regan, M., King, J., Haley, B.A., Kubik, P.W., Garbe-Schönberg, D., 2008. Beryllium isotopes in central Arctic Ocean sediments over the past 12.3 million years: stratigraphic and paleoclimatic implications. Paleoceanography 23, PA1S02.

Funder, S., Hansen, L., 1996. The Greenland Ice Sheet - a model for its culmination and decay during and after the last glacial maximum. Bulletin Geological Society of Denmark 42, 137-152.

Funder, S., Kjær, K.H., Linderson, H., Lyså, A., Olsen, J., 2009. Driftwood and Ice a sketchy history of Holocene multiyear sea ice in the Arctic Ocean. In: Third
Conference on Arctic Paleoclimate and its Extremes. APEX, Copenhagen, Denmark, p. 27.

Grosswald, M.G., Hughes, T.J., 2008. The case for an ice shelf in the Pleistocene Arctic Ocean. Polar Geography 31, 68-69.

Häggblom, A., 1992. Driftwood on Svalbard as an indicator of sea ice conditions. Geografiska Annaler, Series A: Physical Geography 64, 84-94.

Hall, B.L., Baroni, C., Denton, G.H., 2008. The most extensive Holocene advance in the Stauning Alper, East Greenland, occurred in the Little Ice age. Polar Research 27, 128-134

Hall, B.L., Baroni, C., Denton, G.H. 2010. Relative sea-level changes, Schuchert Dal, East Greenland, with implications for ice extent in late-glacial and Holocene times. Quaternary Science Reviews, doi:10.1016/j.quascirev.2010.03.013.

Hanslik, D., Jakobsson, M., Backman, J., Björck, S., Sellén, E., O’Regan, M., Fornaciari, E., Skog, G., 2010. Quaternary Arctic Ocean sea ice variations and radiocarbon reservoir age corrections. Quaternary Science Reviews 29, 3430-3441.

Hogan, K.A., Dowdeswell, J.A., Noormets, R., Evans, J., Cofaigh, C.ó., 2010a. Evidence for full-glacial flow and retreat of the Late Weichselian Ice Sheet from the waters around Kong Karls Land, eastern Svalbard. Quaternary Science Reviews $29,3563-3582$.

Hogan, K.A., Dowdeswell, J.A., Noormets, R., Evans, J., Ó Cofaigh, C., Jakobsson, M., 2010b. Submarine landforms and ice-sheet flow in the Kvitøya Trough, northwestern Barents Sea. Quaternary Science Reviews 29, 3545-3562.

Hughes, T.J., Denton, G.H., Grosswald, M.G., 1977. Was there a late-Würm Arctic ice sheet? Nature 266, 596-602.

Ingólfsson, Ó., Wiig, Ø, 2009. Late Pleistocene fossil find in Svalbard: the oldest remains of a polar bear (Ursus maritimus Phipps, 1744) ever discovered. Polar Research 28, 455-462.

Jakobsson, M., 1999. First high-resolution chirp sonar profiles from the central Arctic Ocean reveal erosion of Lomonsov Ridge sediments. Marine Geology 158, $111-123$.

Jakobsson, M., Løvlie, R., Al-Hanbali, H., Arnold, E., Backman, J., Mörth, M., 2000. Manganese and color cycles in Arctic Ocean sediments constrain Pleistocene chronology. Geology 28, 23-26.

Jakobsson, M., Løvlie, R., Arnold, E.M., Backman, J., Polyak, L., Knutsen, J.-O., Musatov, E., 2001. Pleistocene stratigraphy and paleoenvironmental variation from Lomonosov Ridge sediments, central Arctic Ocean. Global and Planetary Change 31, 1-22.

Jakobsson, M., Spielhagen, R.F., Thiede, J., Andreasen, C., Hall, B., Ingólfsson, O., Kjaer, K.H., van Kolschoten, T., Krinner, G., Long, A., Lunkka, J.P., Subetto, D., Svendsen, J.-I., 2008. Arctic Palaeoclimate and its extremes (APEX). Polar Research 27, 105-113.

Jakobsson, M., Nilsson, J., O’Regan, M., Backman, J., Löwemark, L., Dowdeswell, J.A., Mayer, L., Polyak, L., Colleoni, F., Anderson, L., Björk, G., Darby, D., Eriksson, B., Hanslik, D., Hell, B., Marcussen, C., Sellén, E., Wallin, A.., 2010. An Arctic Ocean ice shelf during MIS 6 constrained by new geophysical and geological data. Quaternary Science Reviews, doi:10.1016/j.quascirev.2010.03.015.

Jansen, E., Raymo, M.E., 1996. Proc. ODP, I.R., 162: College Station, TX (Ocean Drilling Program), 5-20. Leg 162: new frontiers on past climates. In: Jansen, E., Raymo, M.E., Blum, P. (Eds.), Proceedings of the Ocean Drilling Program: Initial Reports. Ocean Drilling Program. Texas A\&M University, Texas College Station.

Jennings, A.E., Hald, M., Smith, M., Andrews, J.T., 2006. Freshwater forcing from the Greenland Ice Sheet during the younger Dryas: evidence from southeastern Greenland shelf cores. Quaternary Science Reviews 25, 282-298.

Johnsen, S.J., Dahl-Jensen, D., Gundestrup, N., Steffensen, J.P., Clausen, H.B., Miller, H., Masson-Delmotte, V., Sveinbjörnsdottir, A.E., White, J., 2001. Oxygen isotope and palaeotemperature records from six Greenland ice-core stations: camp Century, Dye-3, GRIP, GISP2, Renland and NorthGRIP. Journal of Quaternary Science 16, 299-307.

Kelly, M., 1980. The status of the Neoglacial in western Greenland. In: Undersøgelse, G.G. (Ed.), Grønlands Geologiske Undersøgelse, pp. 1-24

King, E.C., Hindmarsh, R.C.A., Stokes, C.R., 2009. Formation of mega-scale glacial lineations observed beneath a West Antarctic ice stream. Nature Geosci 2, 585-588.

Krylov, A.A., Andreeva, I.A., Vogt, C., Backman, J., Krupskaya, V.V., Grikurov, G.E., Moran, K., Shoji, H., 2008. A shift in heavy and clay mineral provenance indicates a middle Miocene onset of a perennial sea ice cover in the Arctic Ocean. Paleoceanography 23, PA1S06.

Kuijpers, A., Troelstra, S.R., Prins, M.A., Linthout, K., Akhmetzhanov, A., Bouryak, S., Bachmann, M.F. Lassen, S., Rasmussen, S., Jensen, J.B., 2003. Late Quaternary sedimentary processes and ocean circulation changes at the Southeast Greenland margin. Marine Geology 195, 109-129.

Larsen, N.K., Kjær, K.H., Funder, S., Möller, P., van der Meer, J.J., Schomacker, A., Linge, H., Darby, D., 2010. Late Quaternary glaciation history of northernmost Greenland - Evidence of shelf-based ice. Quaternary Science Reviews 29, 3399-3414.

Ledu, D., Rochon, A., de Vernal, A., St-Onge, G., 2010. Holocene paleoceanography of the northwest passage, Canadian Arctic Archipelago. Quaternary Science Reviews, doi:10.1016/j.quascirev.2010.06.018.

Lindqvist, C., Schuster, S.C., Sun, Y., Talbot, S.L., Qi, J., Ratan, A., Tomsho, L.P. McClellan, L., Zhang, Y., Zeyl, E., Ehrich, D., Aars, J., Miller, W., Ingólfsson, Ó., Bachmann, L., Wiig, Ø, 2010. Complete mitochondrial genome of a Pleistocene jawbone unveils the origin of polar bear. Proceedings of the National Academy of Sciences of the United States of America 107, 5053-5057.

Long, A.J., Roberts, D.H., Simpson, M.J.R., Dawson, S., Milne, G.A., Huybrechts, P., 2008. Late Weichselian relative sea-level changes and ice sheet history in southeast Greenland. Earth and Planetary Science Letters 272, 8-18. 
Lourens, L., Hilgen, F., Shackleton, N.J., Laskar, J., Wilson, D., 2004. The Neogene period. In: Gradstein, F., Ogg, J., Smith, A. (Eds.), A Geologic Time Scale 2004, pp. 409-440.

Mercer, J.H., 1970. A former ice sheet in the Arctic Ocean? Palaeogeography, Palaeoclimatology, Palaeoecology 8, 19-27.

Möller, P., Larsen, N.K., Kjær, K.H., Funder, S., Schomacker, A., Linge, H., Fabel, D. 2010. Early to middle Holocene valley glaciations on northernmost Greenland. Quaternary Science Reviews, doi:10.1016/j.quascirev.2010.06.044.

North Greenland Ice Core Project members, 2004. High-resolution record of Northern Hemisphere climate extending into the Last Interglacial period. Nature 431, 147-151.

Not, C., Hillaire-Marcel, C., 2010. Time constraints from ${ }^{230} \mathrm{Th}$ and ${ }^{231} \mathrm{~Pa}$ data in late Quaternary, low sedimentation rate sequences from the Arctic Ocean: an example from the northern Mendeleev Ridge. Quaternary Science Reviews 29 , 3665-3675

Ó Cofaig, C., Dowdeswell, J.A., Evans, J., Kenyon, N.H., Taylor, J., Mienert, A., Wilken, M., 2004. Timing and significance of glacially influenced mass-wasting in the submarine channels of the Greenland Basin. Marine Geology 207, 39-54.

O’Regan, M., King, J.W., Backman, J., Jakobsson, M., Moran, K., Heil, C., Sakamoto, T., Cronin, T., Jordan, R., 2008. Constraints on the Pleistocene chronology of sediments from the Lomonosov Ridge. Paleoceanography 23.

O'Regan, M., Jakobsson, M., Kirchner, N., 2010. Glacial geological implications of overconsolidated sediments on the Lomonosov Ridge and Yermak Plateau. Quaternary Science Reviews, doi:10.1016/j.quascirev.2010.09.009.

Otto-Bliesner, B.L., Marshall, S.J., Overpeck, J.T., Miller, G.H., Hu, A., CAPE-Members, 2006. Simulating Arctic climate warmth and icefield retreat in the last interglaciation. Science 311, 1751-1753.

Polyak, L., Edwards, M.H., Coakley, B.J., Jakobsson, M., 2001. Ice shelves in the Pleistocene Arctic Ocean inferred from glaciogenic deep-sea bedforms. Nature 410, 453-459.

Polyak, L., Alley, R.B., Andrews, J.T., Brigham-Grette, J., Cronin, T.M., Darby, D.A., Dyke, A.S., Fitzpatrick, J.J., Funder, S., Holland, M., Jennings, A.E., Miller, G.H. O’Regan, M., Savelle, J., Serreze, M., St. John, K., White, J.W.C., Wolff, E., 2010. History of sea ice in the Arctic. Quaternary Science Reviews 29, 1757-1778.

Schirrmeister, L., Grosse, G., Kunitsky, V.V., Fuchs, M.C., Krbetschek, M. Andreev, A.A., Herzschuh, U., Babyi, O., Siegert, C., Meyer, H., Derevyagin, A.Y. Wetterich, S., 2010. The mystery of Bunge Land (New Siberian Archipelago): implications for its formation based on palaeoenvironmental records, geomorphology, and remote sensing. Quaternary Science Reviews 29, 3598-3614.

Sejrup, H.P., Gifford, H.M., Brigham-Grette, J., Løvlie, R., Hopkins, D., 1984. Amino acid epimerization implies rapid sedimentation rates in Arctic Ocean cores. Nature 310, 772-775

Sellén, E., O'Regan, M., Jakobsson, M., 2010. Spatial and temporal Arctic Ocean depositional regimes: a key to the evolution of ice drift and current patterns. Quaternary Science Reviews, doi:10.1016/j.quascirev.2010.06.005.

Serreze, M.C., Holland, M.M., Stroeve, J., 2007. Perspectives on the Arctic's shrinking sea-ice cover. Science, 1533-1536.

Simpson, M.J.R., Milne, G.A., Huybrechts, P., Long, A.J., 2009. Calibrating a Glaciological Model of the Greenland Ice Sheet from the Last Glacial Maximum to Present-day Using Field Observations of Relative Sea Level and Ice Extent. Pergamon-Elsevier Science Ltd, pp. 1631-1657.

Spielhagen, R.F., Tripati, A., 2009. Evidence from Svalbard for near-freezing temperatures and climate oscillations in the Arctic during the Paleocene and Eocene. Palaeogeography, Palaeoclimatology, Palaeoecology 278, 48-56.

Spielhagen, R.F., Baumann, K.H., Erlenkeuser, H., Nowaczyk, N.R., NorgaardPedersen, N., Vogt, C., Weiel, D., 2004. Arctic Ocean deep-sea record of northern Eurasian ice sheet history. Quaternary Science Reviews 23, 1455-1483.
St John, K., 2008. Cenozoic ice-rafting history of the central Arctic Ocean: terrigenous sands on the Lomonosov Ridge. Paleoceanography 23, PA1S05.

St. John, K.E.K., Krissek, L.A., 2002. The late Miocene to Pleistocene ice-rafting history of southeast Greenland. Boreas 31, 28-35.

Stickley, C.E., John, K.S., Koc, N., Jordan, R.W., Passchier, S., Pearce, R.B., Kearns, L.E. 2009. Evidence for middle Eocene Arctic sea ice from diatoms and ice-rafted debris. Nature 460, 376-380.

Strand, K. Immonen, N., 2010. Dynamics of the Barents-Kara Ice Sheet as revealed by quartz sand grain microtextures of the Late Pleistocene Arctic Ocean sediments, Quaternary Science Reviews, in this issue.

Straneo, F., Hamilton, G.S., Sutherland, D.A., Stearns, L.A., Davidson, F., Hammill, M.O. Stenson, G.B., Rosing-Asvid, A., 2010. Rapid circulation of warm subtropical waters in a major glacial fjord in East Greenland. Nature Geoscience 3, 182-186.

Stroeve, J., Holland, M.M., Meier, W., Scambos, T., Serreze, M., 2007. Arctic sea ice decline: faster than forecast. Geophysical Research Letters 34 (L09501).

Stroeven, A.P., Fabel, D., Codilean, A.T., Kleman, J., Clague, J.J., Miguens-Rodriguez, M., Xu, S., 2010. Investigating the glacial history of the northern sector of the Cordilleran Ice Sheet with cosmogenic ${ }^{10} \mathrm{Be}$ concentrations in quartz. Quaternary Science Reviews, doi:10.1016/j.quascirev.2010.07.010.

Svendsen, J.I., Alexanderson, H., Astakhov, V.I., Demidov, I., Dowdeswell, J.A., Henriksen, M., Hjort, C., Houmark-Nielsen, M., Hubberten, H.W., Ingólfson, O. Jakobsson, M., Kjær, K., Larsen, E., Lokrantz, H., Lunkka, J.P., Lyså, A., Mangerud, J., Maslenikova, O., Matioushkov, A., Murray, A., Möller, P., Niessen, F. Saarnisto, M., Siegert, C., Stein, R., Siegert, M.J., Spielhagen, R., 2004. Late Quaternary ice sheet history of northern Eurasia. Quaternary Science Reviews 23, 1229-1271.

Thiede, J., Myhre, A.M., 1996. Introduction to the North Atlantic-Arctic gateways: plate tectonic-paleoceanographic history and significance. In: Thiede, J., Myhre, A.M., Firth, J.V., Johnson, G.L., Ruddiman, W.F. (Eds.), Proceedings of the Ocean Drilling Program: Scientific Results. Ocean Drilling Program. Texas A\&M University, Texas College Station.

Thiede, J., Winkler, A., Wolf-Welling, T., Eldholm, O., Myhre, A.M., Baumann, K.-H., Henrich, R., Stein, R., 1998. Late Cenozoic history of the Polar North Atlantic: results from ocean drilling. Quaternary Science Reviews 17, 185-208.

Thiede, J., Astakhov, V., Bauch, H., Bolshiyanov, D.Y., Dowdeswell, J.A., Funder, S., Hjort, C. Kotlyakov, V.M., Mangerud, J., Pyramikov, S.M. Saarnisto, M. Schluechter, C., 2004. What was QUEEN? Its history and international framework-an introduction to its final synthesis issue. Quaternary Science Reviews 23, 1225-1227.

van Donk, J., Mathieu, G., 1969. Oxygen isotope compositions of foraminifera and water samples from the Arctic Ocean. Journal of Geophysical Research 74, 3396-3407.

Vare, L.L., Massé, G., Gregory, T.R., Smart, C.W., Belt, S.T., 2009. Sea ice variations in the central Canadian Arctic Archipelago during the Holocene. Quaternary Science Reviews 28, 1354-1366.

Vernal, A.d., Hillaire-Marcel, C., Solignac, S., Radi, T., 2008. Reconstructing sea ice conditions in the Arctic and Sub-Arctic Prior to human observations. In: deWeaver, E.T., Bitz, C.M., Tremblay, L.-B. (Eds.), Arctic Sea Ice Decline: Observations, Projections, Mechanisms, and Implications. American Geophysical Union, Washington, DC, pp. 27-45.

Vogt, P.R., Crane, K., Sundvor, E., 1994. Deep Pleistocene iceberg plowmarks on the Yermak Plateau: sidescan and $3.5 \mathrm{kHz}$ evidence for thick calving ice fronts and a possible marine ice sheet in the Arctic Ocean. Geology 22, 403-406.

Winkelmann, D., Jokat, W., Jensen, L., Schenke, H.-W., 2010. Submarine end moraines on the continental shelf off NE Greenland e Implications for Lateglacial dynamics. Quaternary Science Reviews 29, 1069-1077. 